\title{
Effect of Nitrogen on the Corrosion Behavior of Austenitic Stainless Steel in Chloride Solutions
}

\author{
W. A. Ghanem ${ }^{1}$, W. A. Hussein ${ }^{2}$, S. N. Saeed ${ }^{1}$, S. M. Bader ${ }^{2} \&$ R. M. Abou Shahba ${ }^{2}$ \\ ${ }^{1}$ Central Metallurgical Research and Development Institute (CMRDI), Tepen, Cairo, Egypt \\ ${ }^{2}$ Chemistry Department, Faculty of Science (Girls), Al-Azhar University, Nasr City, Cairo, Egypt \\ Correspondence: W. A. Hussein, Chemistry Department, Faculty of Science (Girls), Al-Azhar University, Nasr \\ City, Cairo, Egypt. Tel: 20-012-2743-7441. E-mail: Wallaahmed@yahoo.com
}

Received: July 12, 2015

Accepted: August 23, 2015

Online Published: September 30, 2015

doi:10.5539/mas.v9n11p119

URL: http://dx.doi.org/10.5539/mas.v9n11p119

\begin{abstract}
The effect of partial replacement of nickel with nitrogen on the corrosion resistance of newly designed austenitic stainless steel samples without and with heat treated was investigated in $3.5 \mathrm{wt} \%$ and $5 \mathrm{wt} \% \mathrm{NaCl}$ solution using open-circuit, potentiodynamic, cyclic anodic polarization and electrochemical impedance spectroscopy techniques. The results showed that, passivation in sample 1 where the highest addition of nickel and low addition of nitrogen is different from that for sample 4 where the nitrogen is greatest and the nickel is reduced almost to the third comparing sample 1. The difference in responses of heat treated samples to localized and general corrosion could be attributed to the difference in their phase compositions. The appearance of ferrite phase for samples $(2,4,5$ and 6$)$ after heat treatment resulted in lowering the general and localized corrosion resistance than as forged samples in contrast with samples 1 and 3, where they still pure austenite. The obtained results are confirmed by surface examination.
\end{abstract}

Keywords: localized corrosion, pitting corrosion, anodic polarization, nitrogen stainless steel

\section{Introduction}

Nitrogen is considered as an important alloying addition to austenitic stainless steel in terms of corrosion resistance. It promotes passivity, widens the passive range in which pitting is less probable, improves stress corrosion cracking resistance in some media, and enhances the resistance to general and intergranular corrosion (Osozawa \& Okato, 1976, p. 135)(Newman, Lu, Bandy \& Clayton, 1984, p.394)(Mozhi, Nishimoto, Wilde \& Clark, 1986, p.197)(Speidel, 1989, p. 251)(Kamachi, 1993). Moreover, nitrogen dissolved in austenitic stainless steel was found to increase its strength(Osozawa, Okato, Fukase, Yokota \& Boshoku-Gijyutsu, 1975. p.1)(Qian, Zhang, Qiu \& Guo, 2011, p.4065). The following mechanisms have been suggested to explain how nitrogen operates: (1) nitrogen in solid solution is dissolved and produces $\mathrm{NH}_{4}{ }^{+}$, depressing oxidation inside a pit (Osozawa \& Okato, 1976, p. 135) (Osozawa, Okato, Fukase, Yokota \& Boshoku-Gijyutsu, 1975. p.1)(Fermenia, Leygraf \& Lookkonen, 2001, p.1939)(Bandy, Lu, Newman \& Clayton, 1984, p.471); (2) concentrated nitrogen at the passive film/alloy surface stabilizes the film, and prevents attack of anions $\left(\mathrm{Cl}^{-}\right)(\mathrm{Clayton}$, Rosenzweig, Oversluizen \& Lu, 1986, p.323)(Halada, Claton, Kim \& Kearns, 1995, p.531)(Osozawa \& Okato, 1976, p.135)(Newman, Lu, Bandy \& Clayton, 1984, p.394); (3) produced nitrate ions improve the resistance to pitting corrosion(Baba, Kodama \& Katada, 2002, p.2393); (4) nitrogen addition stabilizes the austenitic phase(Jargelivs, 1986); and (5) nitrogen blocks the kink, and controls the increase of electric current for pit production(Olesson, 1995, p.467). In order to develop a resources saving stainless steel with excellent general and localized corrosion resistance, 2 key technologies were adopted. The first key is high nitrogen alloying. Nitrogen enrichment improves pitting and crevice corrosion resistance without increasing chromium or molybdenum content. Therefore, adding nitrogen may contribute to reduce necessary chromium and molybdenum content. Moreover, as nitrogen is austenite former, adding nitrogen lowers the nickel content required for forming a single austenitic phase. Lowering the nickel in stainless steel lowers the costs of production. The aim of this paper is to study the effect of partial replacement of nickel with nitrogen on the corrosion behavior of newly designed austenitic stainless steel samples without and with heat treated. 


\section{Experimental}

The chemical composition of the samples is described in Table 1. The newly designed samples were prepared, cold worked and normalized by steel laboratory in Central Metallurgical Research and Development Institute (CMRDI). The newly austenitic stainless steel samples forged as square rode at $1100{ }^{\circ} \mathrm{C}$. Heat treatment of six samples alloys was carried out at temperature $1050{ }^{\circ} \mathrm{C}$, and then isothermally held for 30 minutes followed by water quenching. Then stress relief for 2 hours at $750-770{ }^{\circ} \mathrm{C}$ followed finally by air cooling. Heat treatment cycle were shown in Figure(1) and the condition after heat treated are listed in Table (2). Austenitic stainless steel (sample 1) was used as the blank material for all the samples. In samples 2- 6 the nitrogen content was varied while the nickel content was gradually decreased.

Experiments were designed to investigate the role of partial replacement of nickel by nitrogen on the corrosion behavior of austenitic stainless steel. The solutions used in this investigation were 3.5 and $5 \mathrm{wt} \% \mathrm{NaCl}$ solution. Open-circuit, potentiodynamic, cyclic anodic polarization and electrochemical impedance spectroscopy were used to test corrosion behavior of the samples in different solutions at $25{ }^{\circ} \mathrm{C}$. Finally scanning electron microscope (SEM) and energy dispersive X-ray analysis (EDAX) was used to detect the morphology of some samples surface. Volta Lab 40(PGZ301)-Radiometer computerized potentiostat was used for testing.

\section{Results and Discussion}

\subsection{Open-Circuit Potential Measurements}

\section{a. Forged samples}

Figures(2,3) show the time dependence open circuit potentials of stainless steel samples in 3.5 and $5 \mathrm{wt} \% \mathrm{NaCl}$ solutions. The curves showed general tendency for the initial open circuit potential values to shift towards more negatives.

From the values of immersion potential $\left(\mathrm{E}_{\mathrm{im}}\right)$ and steady state potential $\left(\mathrm{E}_{\mathrm{s} . \mathrm{s}}\right)$ which presented collectively in Tables 3, it is concluded that:

- Sample 4 which contains the highest amount of nitrogen was having more positive $\mathrm{E}_{\mathrm{im}}$ and $\mathrm{E}_{\mathrm{s} . \mathrm{s}}$ values indicating passive film formation on the sample surface.

- In contrast, curves indicated that, sample 2, due to the lowest percentage of nitrogen and the highest percentage of carbon, showed the most negative $\mathrm{E}_{\mathrm{im}}$ and $\mathrm{E}_{\mathrm{s.s}}$ values.

- Sample 1 with the highest percentage of nickel showed the most positive $\mathrm{E}_{\mathrm{im}}$ and $\mathrm{E}_{\mathrm{s} . \mathrm{s}}$ values which facilitate passivation and producing more stable passive film.

- For samples 3,5 and 6, $\mathrm{E}_{\mathrm{im}}$ and $\mathrm{E}_{\mathrm{s} . \mathrm{s}}$ values shifted to more positive with increasing in nitrogen content in tested samples.

The passive film acts as barrier, separating the sample surface from the corrosive ions in the environment. Thus the understanding of the corrosion resistance of the stainless steel lies in comprehending the properties of the passive film formed on the stainless steel. The passive film formed on high nitrogen stainless steel surface in $\mathrm{NaCl}$ solutions was n-type semiconductor (Qian, Zhang, Qiu \& Guo, 2011, p.4065).

\section{b. Heat Treated Samples:}

Figure(4) shows typical comparison between open-circuit potential measurements for as forged and heat treated test alloys in $3.5 \mathrm{wt} \% \mathrm{NaCl}$ solution.

Analysis of the curves Figure(4) show that, the open-circuit potential of sample 1 after heat treatment had a tendency to shift in positive direction, but as forged was almost stable at low negative value, this results indicating that, the heat treatment improved the corrosion resistance of sample 1. While other samples showed potential drop to the negative direction for both the as-forged and heat treated samples indicating dissolution of the oxide film formed on the surface of these samples. Open-circuit potential for heat treated samples increases than the as forged for samples, 2 and 3, decrease for sample 4 and 6 or almost the same in samples 5 .

\subsection{Potentiodynamic Polarization Measurements}

\section{a. Forged samples:}

Figures $(5,6)$ represent the potentiodynamic polarization measurements of stainless steel samples in aerated 3.5 and $5 \mathrm{wt} \% \mathrm{NaCl}$ solution using scanning rate $2 \mathrm{mV} / \mathrm{sec}$ in potential range from -500 to $2000 \mathrm{mV}(\mathrm{SCE})$ at $25^{\circ} \mathrm{C}$. According to Figs $(5,6)$, for six samples in 3.5 and $5 \mathrm{wt} \% \mathrm{NaCl}$ solutions, the polarization curves can be put into two groups. A first group with samples 2, 3 and 5 show anodic dissolution, the $\mathrm{Cl}^{-}$ions prevent passivation to occur. A second group with samples 1, 4 and 6 there is a general tendency for passivation. The break in current 
as the potential increases explains this passivation. The passivation current was taken as the average current of the passive region.

The superior behavior of samples 1 and 4 over the rest samples was confirmed from the corrosion kinetic parameter which listed in Table (4), where:

For sample 1, where the highest Ni content $\sim 9 \mathrm{wt} \%$ and low nitrogen content $\sim 0.028 \mathrm{wt} \%$, the zero current potential, Ecorr, shifted to more positive value $2.3 \mathrm{mV}$ than the other samples and passivation current is estimated to be about $0.06 \mathrm{~mA}$. The passivation region extended to higher potential which is shifted to more positive. The break in this passive region occurred at almost $0.8 \mathrm{~V}$.

1) For sample 4 , where the highest $\mathrm{N}$ content $\sim 0.24 \mathrm{wt} \%$ and $\mathrm{Ni}$ content reducing to the third comparing sample 1, the passivation occurred by a slight decrease in current followed by passivation region started at $0.01 \mathrm{~mA}$ and extended to more positive higher potential. The break down potential is observed at $\sim 1.25 \mathrm{~V}$.

2) For samples from 2 to 6 the corrosion current density, $I_{\text {corr }}$, and the corrosion rate are decreased with increasing in the nitrogen contents without respect to the percentage of $\mathrm{Ni}$.

Increasing in $\mathrm{NaCl}$ concentration to $5 \mathrm{wt} \%$,Figure(6), lead to decrease in break down potential and shrinkage in passive region for samples 1 and 4 in comparison with that in $3.5 \mathrm{wt} \% \mathrm{NaCl}$ solution. As clear from Table(5), for six samples, the corrosion current density, Icorr, was shifted to higher values which suggested worse behavior of all samples by increasing in $\mathrm{NaCl}$ concentration. In addition the results reveal that the value of $\mathrm{I}_{\text {corr }}$ depends also on the composition of the alloys at a given $\mathrm{NaCl}$ concentration.

A general view to the potentiodynamic curves of Figure $(5,6)$ and corrosion parameters of Tables $(4,5)$, reveals that nitrogen promote passivation of nitrogen stainless steel and passivation requires a certain proportion of nickel to be present.

It is worthy to observe that the mode of passivation in sample 1 where there is a high addition of nickel and low addition of nitrogen is different from that for sample 4 where the nitrogen is greatest and the nickel is reduced almost to the third comparing sample 1. In sample1, anodic current is almost the lowest. In sample 4, the current decreases greatly with increasing the potential and passivation takes place over a wide range of potential.

It could be possible that the corrosion property was improved in sample1, mainly due to the high nickel contents which led to an increase in the coarseness of the grain size and a corresponding decrease in grain boundaries. Since local corrosion events usually start at electrochemical active site such as grain boundaries (Fermenia, Leygraf \& Lookkonen, 2001, p.1939), it is therefore believed that lower corrosion rate which observed in sample 1 was due to lower amounts of electrochemical active site occurring at these grain boundaries. The highest nickel content $9.05 \%$ would have been expected to make sample 1 the most resistance to uniform corrosion.

In terms of passive film properties for sample $4, \mathrm{~N}$ has been observed to decrease the passive current density. It is also widely admitted that $\mathrm{N}$ accelerates repassivation, both for Fe-N alloys (Bandy, Lu, Newman \& Clayton, 1984, p.471) (Clayton, Rosenzweig, Oversluizen \& Lu, 1986, p.323) (Halada, Claton, Kim \& Kearns, 1995, p.531) and for stainless steels (Osozawa \& Okato, 1976, p.135) (Newman, Lu, Bandy \& Clayton, 1984, p.394), particular in presence of chloride. Scratch repassivation experiments have shown that $\mathrm{N}$ dissolving in steel has a strong capacity to promote repassivation (Baba, Kodama \& Katada, 2002, p.2393). Upon dissolution of the steels, mainly $\mathrm{NH}_{4}{ }^{+}$is formed from the dissolved nitrogen. Most probably nitrogen from the metal surface, segregated in a negatively charged state, is directly converted according to the chemical reaction:

$$
\mathrm{N}^{3-}+4 \mathrm{H}^{+} \longrightarrow \mathrm{NH}_{4}^{+}
$$

The formation of ammonium ions consumes protons and there by increases the $\mathrm{pH}$ which buffering the solution in the passive layer region (Jargelivs, 1986) (Olesson, 1995, p.467).

\section{b. Heat Treated Samples:}

Figure(7) show typical comparison between potentidynamic polarization measurements for as forged and heat treated test samples in $3.5 \mathrm{wt} \% \mathrm{NaCl}$ solution.

The difference in responses of theses alloys to general corrosion could be attributed to the difference in their phase compositions. The appearance of ferrite phase for samples $(2,4,5$ and 6$)$ after heat treatment result in lowering the general corrosion resistance than as forged samples in contrast with samples 1 and 3, where they still pure austenite. In heat treated samples $(2,4,5$ and 6$)$, the ferrite phase would be anodic towards the austenite one which might possibly result in selective dissolution of the ferrite phase leading to lowering the general corrosion resistance of these samples. So while the ferrite phase increases, there is a gradual decrease in corrosion resistance of these samples. This was also confirmed by previous work of Yau and Stericher(Yau \& 
Streicher, 1988, p. 220), Cortie and Potgieter(Cortie \& Potgieter, 1991, p. 2173)and from the electrochemical parameters, Table 6. Samples 1 and 3 have lower corrosion current densities, Icorr hence lower corrosion rate than as forged but the heat treated samples 2, 4, 5 and 6, have higher $\mathrm{I}_{\text {corr. }}$ values than as forged ones.

\subsection{Potentiodynamic Cyclic Anodic Polarization Measurements}

\section{a. Forged Samples:}

Figures $(8,9)$ represent the potentiodynamic cyclic anodic polarization measurements for six samples in $3.5 \mathrm{wt} \%$ and $5 \mathrm{wt} \%$ sodium chloride solutions using scan rate $2 \mathrm{mV} / \mathrm{sec}$ in potential range from -500 to $2000 \mathrm{mV} / \mathrm{sec}$ at $25^{\circ} \mathrm{C}$.

As is clear from Figures $(8,9)$, after the corrosion potential, the anodic current density starts to increase to form the active region. The increase of the potential in the positive directions lead to increasing of the anodic current, which corresponds to oxidation of iron to iron ions, with increasing the potential a passive film $\left[\mathrm{Fe}(\mathrm{OH})_{2}, \mathrm{Fe}_{3} \mathrm{O}_{4}\right.$ and or $\mathrm{Fe}_{2} \mathrm{O}_{3}$ ] conform(M.Poubaix, 1974). When the potential move towards more anodic, the current density starts to increase again, forming the transpassive region before oxygen evolution. The current rises suddenly without any sign of oxygen evolution for samples 2, 3, 5 and 6 , denoting break down of the passive layer, when the polarization potential reaches a certain critical potential $\left(\mathrm{E}_{\mathrm{pit}}\right)$.

Hysteresis loop area is a rough measure of the intensity of pitting corrosion. Larger size means greater intensity of pitting corrosion (Bikic, Rizvanovic and Avdusinovic, 1973, p. 471).

For samples 1 and 4 in $3.5 \mathrm{wt} \% \mathrm{NaCl}$ solution, the cyclic polarization curves don't have a hysteresis loop where the forwards scan current density are higher than back words at the same potential, indicating the good stability and self repairing ability of the passive film. For the rest samples, the hysteresis loops were observed.

As shown from Figure (8), the hysteresis loop area is increased with decreasing in the nitrogen content of the sample reaching its maximum area in sample 2 where the lowest nitrogen content sample.

As noted, it is the formation of the chromium - rich oxide layer that accounts chiefly for the corrosion resistance of stainless steel. However, this layer is susceptible to damage, particularly in the presence of chlorides, and such damage can lead to the onset of localized corrosion such as pitting and crevice corrosion. Nickel does not influence the initiation phase but is important in reducing the rate at which both pitting and crevice corrosion propagates. This is critical in determining how serious corrosion will be and this explain the highly pitting resistance of sample 1(Okatmot, 1973, p. 471).

For sample 4, the improvement in the pitting resistance is due to the highest nitrogen content. Nitrogen in the stainless steel improves pitting and crevice corrosion resistance by the ways consumption of the acid in the pit nuclei leading to $\mathrm{NH}_{4}{ }^{+}$formation (Palit, Kain \& Gadyiyar, 1993, p. 979), enrichment of nitrogen on the passivated surface and enrichment of nitrogen on the active surface (Byrives, Grujcic and Owen, 1987, p. 1853)( Newman \& Shahrabi, 1987, p. 827). Thus the oxide rupture strain should increase due to better stability and improved characteristics of the passive film resulting in a reduction in the passive film breakage frequency.

Regarding the manganese effect the addition of this element didn't modify significant corrosion behavior of the stainless steels, due to the low ability of $\mathrm{Mn}(\mathrm{II})$ to form in soluble compound(Bautista, Blanco, Velasco, Gutierrez, Soriano, Palomares \& Takenouti, 2009, p.785). Moreover, the increase in the manganese content lead to increasing in manganese oxide inclusions which creates more pit initiation sites in the alloy (Pardo, Merino, Coy, Viejo, Arrabal \& Matykina, 2008, p. 780). Thus, for sample 2, the largest hysteresis loop area may be due to the high manganese content, $8.38 \%$, in addition to the lowest nitrogen content, $0.026 \%$.

As the concentration of sodium chloride increased to $5 \mathrm{wt} \%$ Figure(9), the potentiodynamiccyclic anodic polarization curves indicated the presence of pitting or crevice corrosion break down potential which sustained the increase of anodic current density. Samples 1 and 4 failed facing rising in sodium chloride concentration and according to Fig (9), for all stainless steel samples the occurrence of the hysteresis loop is related to the presence of aggressive solution formed inside the occluded area which maintain when the potential was reversed.

As clear from the corrosion parameters, Tables $(7,8)$, for samples (2 to 6 ) the corrosion current, $I_{\text {corr. }}$, decreased and pitting potential, $\mathrm{E}_{\text {pit }}$, increased with increasing nitrogen contents. Moreover, an increase in $\mathrm{NaCl}$ concentration shift $\mathrm{E}_{\mathrm{pit}}$ of all samples towards more negative (active) direction, indicating a decrease of pitting corrosion resistance. A linear dependence coexists between $\mathrm{E}_{\text {pit }}$ and $\log$ concentration of $\mathrm{Cl}$ - ions, satisfying the following equation:

$$
\mathrm{E}_{\mathrm{pit}}=\mathrm{a}-\mathrm{b} \log \mathrm{C}_{\mathrm{Cl}}^{-}
$$


Where (a) and (b) are constants depend upon the composition of the alloys. The values of Epit at any given $\mathrm{Cl}^{-}$ concentration depend upon chemical composition of the samples.

The data reveal that, the value of Epit for the samples (at constant $\mathrm{NaCl}$ concentration) follow the sequence

Sample:

$$
1 \approx 4>6>3>5>2
$$

This sequence reflects the beneficial effects of nitrogen in the alloy. Element has beneficial effects on pitting resistance shift Epit to more positive potentials. It is clear that higher content of $\mathrm{N}$ (sample 4) not only reduce susceptibility to pit nucleation, but also diminish rate of pit growth.

\section{B. Heat Treated Samples:}

Potentiodynamic cyclic anodic polarization measurements for the comparison between as forged and heat treated samples in $3.5 \mathrm{wt} \% \mathrm{NaCl}$ solution are shown in Figure 10.

From Figure 10, the following facts can be summarizing:

- The heat treatment for sample 1 and 4 did not affect the cyclic polarization curves where still no hysteresis loop as the forward scan current densities are higher than back words at the same potential which indicating good stability of the passive film after heat treatment.

Sample 1 is still pure austenite after heat treatment with the highest $\mathrm{Ni}$ content leading to considerable improvement of the pitting properties. Since nickel is less readily oxidized than iron and chromium, there could be enrichment of nickel in its metallic state in the metal closet to the oxide, metal interface, there by prolonging the passive region (Potgieter, Olubambi, Cornish, Machio \& El- Sayed, 2008, p. 2572).

For sample 4 although ferrite phase where appeared after heat treatment, but, the highest nitrogen content of this sample act as strong austenite ( $\mathrm{\gamma}$ ) stabilizer, makes it possible to retain austenite phase with reduction in ferrite phase. And, due to the moderate nickel content in this sample, $3.38 \mathrm{wt} \%$, it could be possible that the pitting resistance after heat treatment mainly due to the effect of $\mathrm{Ni}$ on the volume fraction of ferrite and austenite. The reduction of ferrite phase urged chromium atoms moved into austenite phase and there by increased the relative amount of $\mathrm{Cr}$ in austenite phase, which meant that the pitting resistance of austenite phase (Da- Wei, Change- Sheng, Xiang-juan, Jun, Lu-lu \& Xue-Shan, 2012, p. 50).

- The heat treatment for the rest samples $(2,3,5,6$, ) has deteriorated effect on their pitting resistance comparing as forged samples.

Ha et al (Ha, Thand \& $\mathrm{Sj}, 2012, \mathrm{p} .80$ ), investigated the pitting corrosion resistance of nitrogen stainless steel and showed that, the combination of $\mathrm{N}$ and $\mathrm{C}$ addition enhances pitting corrosion resistance by achieving the protection passive film, however, the pitting corrosion resistance deteriorated by lamellar $\mathrm{Cr}_{2} \mathrm{~N}$ precipitate formed during aging at $900{ }^{\circ} \mathrm{C}$. Table 9 , represent the electrochemical parameters $\mathrm{E}_{\mathrm{pit}}, \mathrm{E}_{\text {corr }}, \mathrm{I}_{\text {corr }}$ and corrosion rate for the heat treated six samples. Data from Table 9 shows the superior behavior of heat treated of samples 1 and 4 comparing as forged one and vies versa the rest samples.

\subsection{Electrochemical Impedance Spectroscopy (EIS)}

\section{Forged Samples:}

The analysis of Nyquist plots from experimental data is done by using circuit in Figure (11) in which $\left(\mathrm{R}_{\mathrm{s}}\right)$ represents the electrolyte resistance; $\left(\mathrm{R}_{\mathrm{ct}}\right)$ represents the charge transfer resistance and the constant phase element $\left(\mathrm{C}_{\mathrm{PE}}\right)$.

The impedance spectra of six stainless steel samples in 3.5\% and $5 \mathrm{wt} \%$ of sodium chloride solutions were investigated at open circuit potentials at room temperature. The impedance data are presented as Nyquist plot for six stainless steel alloys in Figures $(12,13)$.

In Figure(12), in case of sample 1 and 4 which contain the highest percentage of nickel and nitrogen respectively. The capacitive loops for two samples were broad, indicating better film stability. In general, the samples surface is covered with continuous oxide film (Qiao, Zheng, Ke \& Okafor, 2009, p.979).

The Nyquist plots of stainless steel samples 2, 3, 5 and 6 in Figure(12) show a depressed semicircular shape. This observation indicates that the corrosion of stainless steel in $3.5 \% \mathrm{NaCl}$ solution is mainly controlled by a charge transfer process. The Nyquist plots are not perfect semicircles and generally attributed to the frequency dispersion and mass transport resistant as well as electrode surface heterogeneity resulting from surface roughness, impurities, dislocations, grain boundaries and formation of porous layer (Machnikova, Pazderova, Bazzaoui \& Hackerman, 2008, p.1543).

Figure (13) represent the Nyquist plots for all tested stainless steel samples in $5 \% \mathrm{NaCl}$ solution. Inspection of 
these curves shows that, all spectra exhibited a similar behavior except sample 1 .

Sample 1 shows a straight line with a high magnitude of impedance, which indicated the presence of a highly resistant passive film. This confirm that the high percentage of nickel facilitate passivation and produce more stable passive film.

Clearly all the impedance spectra for other samples $2,3,4,5$ and 6 exhibit one single depressed semicircle, which indicates that the corrosion of stainless steel is mainly controlled by a charge transfer process, and usually related to the charge transfer of the corrosion and double layer behavior. These capacitive loops are not perfect semicircles which can be attributed to the frequency dispersion effect as a result of the roughness and in homogeneousness of electrode surface. The diameter of the capacitive loop depends on the composition of the test samples.

The main parameters deduced from the analysis of Nyquist diagram which reported in Tables $(10,11)$ are:

- The resistance of charge transfer $\mathrm{R}_{\mathrm{ct}}$ (diameter of high frequency semicircle)

- The capacity of double layer $\mathrm{C}_{\mathrm{dl}}$ which is defined as:

$$
\mathrm{C}_{\mathrm{dl}}=1 / 2 \pi \mathrm{f}_{\max } \mathrm{R}_{\mathrm{ct}}
$$

Where $\mathrm{f}_{\max }$ is the maximum frequency. c- The degree of surface coverage $(\theta)$ is calculated from the EIS data.

From the impedance data given in Table $(10,11)$, we conclude that:

- The value of Rct increases in the order sample

$$
1>4>6>3>5>2
$$

this can be attributed to the formation of protective film on alloy / solution interface.

On the other hand, the high Rct values are generally associated with lower corroding sample (Machnikova,

Pazderova, Bazzaoui \& Hackerman, 2008, p.1543).

- The value of double layer capacitance Cdl decreases in the order:

sample $2>5>3>6>4>1$. This attributed to increase in thickness of electric double layer, suggested that samples 1 and 4 give a better protection against the corrosion. This agreement with the results obtained from the other electrochemical techniques.

\section{a. Heat Treated Samples:}

Nyquist impedance plots obtained for the comparison between as forged and heat treatment alloys of stainless steel in $3.5 \mathrm{wt} \% \mathrm{NaCl}$, Figure 14, showed single semicircle shifted along the real impedance $\left(Z_{\text {real }}\right)$ axis. For both as forged and heat treatment the shape of figure almost the same with the small increasing or decreasing the values of real impedance $\left(Z_{\text {real }}\right)$ and frequency. The result were interpreted as mentioned before.

\subsection{Spectroscopic Surface Examination}

\section{a. Scanning Electron Microscope (SEM):}

Figures $(15,16)$ illustrates the scanning electron microscope images which describe the morphology of samples no. 1, 2 and 4 after potentiodynamic polarization in $3.5 \mathrm{wt} \% \mathrm{NaCl}$ solutions. Figures $(15(\mathrm{a}, \mathrm{b}))$ show no evidence of corrosion attack and formation of passive film on alloy surfaces. This observation indicates that samples no. 1 and 4 gave excellent corrosion resistance due to the protective passive film with the thickness of a few nanometers formed on the surface of the samples. While Figure $(15, \mathrm{c})$ which belong to the alloy no. 2 in $3.5 \mathrm{wt} \%$ $\mathrm{NaCl}$ solution showed that, the surface of the samples was highly corroded. The corroded areas are shown as grooves in the sample with gray and white products.

Figures $(16, a-c)$ showed the scanning electron microscope images which describe the morphology of the surface of the tested samples no. 1,2 and 4 after potentiodynamic polarization measurements in $3.5 \mathrm{wt} \% \mathrm{NaCl}$ solution after heat treated. As can be seen the samples no 1 and 4 were free of any corrosion attack, and possesses a single austenite phase and two phases austenite and ferrite respectively. But sample no .2, exhibit decreasing in the level of corrosion than before heat treatment.

The (SEM) results are in good agreement with the electrochemical measurements results.

\section{b. Energy Dispersive X-Ray Analysis (EDAX):}

Figure(17) show the energy dispersive X-ray analysis (EDAX) for samples no. 1, 2 and 4 in $3.5 \mathrm{wt} \% \mathrm{NaCl}$ solutions at room temperature.

The observed spectra indicated the presence of $\mathrm{Fe}, \mathrm{Cr}, \mathrm{Ni}, \mathrm{O}, \mathrm{C}, \mathrm{S}$ and $\mathrm{Cl}$ ions. According to the peak strength $\mathrm{Fe}$ and $\mathrm{Cr}$ dominates the component of the film, though the peak of the nitrogen is not appear so nitrogen peak 
intensity is independent of the nitrogen content (Qiao, Zheng, Ke \& Okafor, 2009, p.979). The presence of chloride ion on the passive film is known to create a concentration gradient that facilitates its diffusion into the film, where it undergoes hydrolysis and reduces the local $\mathrm{pH}$, causing dissolution of the film (YQiao, YZheng, Ke \& Okafor, 2009, p.979).

\section{Conclusion}

- The general and localized corrosion attack was found to be retarded by nitrogen addition and the samples were able to passivate as the nitrogen content is increased.

- Addition of nitrogen to stainless steel promotes the passivation but passivation requires a certain proportion of nickel to be present.

- The difference in responses of heat treated samples to general and localized corrosion could be attributed to the difference in their phase compositions. So while the ferrite phase increases, there is a gradual decrease in corrosion resistance of these samples.

\section{References}

Baba, H., Kodama, T., \& Katada, Y. (2002). Corrosion Science, 44, 2393.

Bandy, R., Lu, Y. C., Newman, R. C., \& Clayton, C. R. (1984). Proc. Electrochem.Soc, 84, 471.

Bautista, A., Blanco, G., Velasco, F., Gutierrez, A., Soriano, L., Palomares, F. J., \& Takenouti, H. (2009). Corrosion Science, 51, 785.

Bikic, F., Rizvanovic, M., \& Avdusinovic, H. (2013). Trendsin the development of Machinery andAssociated Technology, TMT 2015, Istanbul, Tprkya, 10-11 September.

Byrives, M. L. G., Grujcic, M., \& Owen, W. S. (1987). ActaMetall, 35, 1853.

Clayton, C. R., Rosenzweig, L., Oversluizen, M., \& Lu, Y. C. (1986). Proc. Electrochemical Society, 86-87, 323.

Cortie, M. B., \& Potgieter, J. H. (1991). Metallurgical Transactions, A22A, 2173.

Da-Wei, J., Change-Sheng, G., Xiang-juan, Z., Jun, L., Lu-lu, S., \& Xue-Shan, X. (2012). Iron and Steel research, International, 19(2), 50.

Fermenia, M., Leygraf, J. P. C., \& Lookkonen, P. (2001). Corrosion Science, 43, 1939.

Halada, G. P., Claton, C. R., Kim, D., \& Kearns, J. R. (1995). NACE/Corrosion, 531.

Hy. Ha., Thand, L., \& Sj, K. (2012). ElectrochimActa, 9, 80.

Jargelivs v. (1986). Report of Swedish ins. For Metal.Research, M2179.

Kamachi, U. (1993). Pitting, intergranular corrosion and passive film in nitrogen bearing austenitic stainless steels, Ph. D. Thesis, University of Madras, Madras, India.

Machnikova, E., Pazderova, M., Bazzaoui, M., \& Hackerman, N. (2008). Surf.Coat. Technol, 202, 1543.

Mozhi, T. A., Nishimoto, K., Wilde, B. E., \& Clark, W. A. T. (1986). Corrosion, 42, 197.

Newman, R. C., \& Shahrabi, T. (1987). Corrosion Science, $27,827$.

Newman, R. C., Lu, Y. C., Bandy, R., \& Clayton, C. R. (1984). Proceedings of the Ninth International Congress on Metallic Corrosion, vol. 1. National Research Council, Canada, Toronto, p.394.

Newman, R. C., Lu, Y. C., Bandy, R., \& Clayton, C. R. (1984). Proc. 9th Int. Conf. Metallic Corrosion, 3, Toronto, 394.

Okatmot, G. (1973). Corrosion Science, 13, 471.

Olesson, C. O. A. (1995). Corrosion, Science, 37, 467.

Osozawa, K., \& Okato, N. (1976). NACE, Honolulu, 135.

Osozawa, K., \& Okato, N. (1976). Passivity and its Breakdown on Iron and Iron-Base Alloys, NACE, Houston, USA, 135.

Osozawa, K., Okato, N., Fukase, Y., Yokota, K., \& Boshoku, G. (1975). Corros. Eng., $24,1$.

Palit, G. C., Kain, V., \& Gadyiyar, H. S. (1993). Corrosion, 49, 979.

Pardo, A., Merino, M. C., Coy, A. E., Viejo, F., Arrabal, R., \& Matykina, E. (2008). Corrosion Science, 50, 780.

Potgieter, J. H., Olubambi, P. A., Cornish, L., Machio, C. N., \& El-Sayed, M. (2008). Corrosion Science, 50, 
2572.

Poubaix, M. (1974). National Association of corrosion Engineering. Houston, Tx, USA.

Qian, Hu., Zhang, G., Qiu, Y., \& Guo, X. (2011). Corrosion Science, 53, 4065.

Qiao, Y. X., Zheng, Y. G., Ke, W., \& Okafor, P. C. (2009). Corrosion Science, 51, 979.

Speidel M. O., Foct J., \& Hendry A. (1989). Proceddings of the International Conference on High Nitrogen steels HNS 88, The Institute of Metals, London, UK, p. 251.

Yau, Y. H., \& Streicher, M. A., STP 978 (1988). ASTM international "Galvanic Corrosion ", 220.

\section{Appendix}

Table 1. The chemical composition of the samples used, mass \%

\begin{tabular}{ccccccccccc}
\hline Sample \# & $\mathrm{Cr}$ & $\mathrm{Ni}$ & $\mathrm{N}$ & $\mathrm{Mn}$ & $\mathrm{Si}$ & $\mathrm{V}$ & $\mathrm{C}$ & $\mathrm{P}$ & $\mathrm{S}$ & $\mathrm{Fe}$ \\
\hline 1 & 18.01 & 9.05 & 0.028 & 0.92 & 1.75 & .0115 & 0.15 & 0.016 & 0.020 & bal. \\
2 & 19.1 & 5.51 & 0.026 & 8.38 & 1.16 & 0.106 & 0.24 & 0.022 & 0.028 & bal. \\
3 & 20.18 & 5.36 & 0.222 & 6.37 & 2.0 & 0.103 & 0.22 & 0.015 & 0.025 & bal. \\
4 & 20.1 & 3.38 & 0.240 & 7.03 & 2.6 & 0.103 & 0.19 & 0.022 & 0.016 & bal. \\
5 & 20.2 & 2.76 & 0.030 & 9.89 & 1.08 & 0.106 & 0.15 & 0.022 & 0.011 & bal. \\
6 & 20.7 & 0.16 & 0.235 & 4.04 & 2.7 & 0.060 & 0.13 & 0.030 & 0.015 & bal. \\
\hline
\end{tabular}

Table 2. Phases of the heat treated stainless steel samples

\begin{tabular}{cl}
\hline Sample No. & \multicolumn{1}{c}{ Phases } \\
\hline 1 & Pure austenite \\
2 & Austenite + ferrite \\
3 & Pure austenite \\
4 & Austenite + ferrite \\
5 & Austenite + ferrite \\
6 & Austenite + ferrite \\
\hline
\end{tabular}

Table 3. Values of $\mathrm{E}_{\mathrm{im}}$ and $\mathrm{E}_{\mathrm{s} . \mathrm{s}}$ for samples in different concentrations of $\mathrm{NaCl}$ solutions

\begin{tabular}{|c|c|c|c|}
\hline Conc. & $\begin{array}{c}\text { Sample } \\
\text { No. }\end{array}$ & & \\
\hline \multirow{7}{*}{ 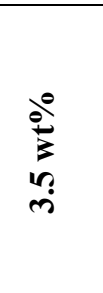 } & & $\mathrm{E}_{\mathrm{im}}(\mathrm{V})$ & $\mathrm{E}_{\mathrm{s} . \mathrm{s}}(\mathrm{V})$ \\
\hline & 1 & -0.136 & -0.180 \\
\hline & 2 & -0.446 & -0.577 \\
\hline & 3 & -0.337 & -0.425 \\
\hline & 4 & -0.138 & -0.380 \\
\hline & 5 & -0.419 & -0.465 \\
\hline & 6 & -0.402 & -0.423 \\
\hline \multirow{6}{*}{$\frac{e^{\circ}}{i n}$} & 1 & -0.353 & -0.393 \\
\hline & 2 & -0.415 & -0.590 \\
\hline & 3 & -0.425 & -0.481 \\
\hline & 4 & -0.133 & -0.431 \\
\hline & 5 & -0.375 & -0.486 \\
\hline & 6 & -0.401 & -0.433 \\
\hline
\end{tabular}

Table 4. The corrosion parameters of six samples in $3.5 \mathrm{wt} \% \mathrm{NaCl}$, solution

\begin{tabular}{cccccc}
\hline $\begin{array}{c}\text { Sample } \\
\text { No. }\end{array}$ & $\begin{array}{c}E_{\text {corr }} \\
(\mathbf{m V})\end{array}$ & $\begin{array}{c}\mathrm{I}_{\text {corr }} \\
\boldsymbol{\mu} \mathbf{A} / \mathbf{c m}^{2}\end{array}$ & \multicolumn{2}{c}{$\begin{array}{c}\text { Tafel Slopes } \\
\boldsymbol{\beta}_{\mathbf{a}} \mathbf{m V} \boldsymbol{\beta}_{\mathbf{c}}\end{array}$} & $\begin{array}{c}\text { Corrosion rate } \\
\boldsymbol{\mu m} / \mathbf{y}\end{array}$ \\
\hline 1 & 2.30 & 9.06 & 119.60 & -154.60 & 106.00 \\
2 & -393.30 & 47.50 & 158.60 & -620.30 & 555.20 \\
3 & -209.80 & 35.72 & 201.70 & -314.90 & 417.80 \\
4 & -168.70 & 10.54 & 120.00 & -148.70 & 123.30 \\
5 & -310.50 & 36.21 & 232.10 & -166.80 & 423.60 \\
\hline
\end{tabular}




\begin{tabular}{llllll}
\hline 6 & -201.50 & 12.98 & 126.10 & -44.00 & 151.90 \\
\hline
\end{tabular}

Table 5. The corrosion parameters of six samples in $5 \mathrm{wt} \% \mathrm{NaCl}$ solution

\begin{tabular}{cccccc}
\hline $\begin{array}{c}\text { Sample } \\
\text { No. }\end{array}$ & $\begin{array}{c}E_{\text {corr }} \\
(\mathbf{m V})\end{array}$ & $\begin{array}{c}\mathrm{I}_{\text {corr }} \\
\boldsymbol{\mu A} \mathbf{A} / \mathbf{c m}^{2}\end{array}$ & \multicolumn{2}{c}{$\begin{array}{c}\text { Tafel Slopes } \\
\boldsymbol{\beta}_{\mathbf{a}} \mathbf{m V} \boldsymbol{\beta}_{\mathbf{c}}\end{array}$} & $\begin{array}{c}\text { Corrosion } \\
\text { rate } \boldsymbol{\mu m} / \mathbf{y}\end{array}$ \\
\hline 1 & -6.10 & 23.08 & 195.10 & -351.80 & 270.00 \\
2 & -400.50 & 2494.30 & 346.70 & -192.80 & 29170.00 \\
3 & -215.50 & 98.74 & 110.40 & 304.70 & 1155.00 \\
4 & -190.70 & 26.70 & 188.50 & -163.00 & 312.30 \\
5 & -350.80 & 1236.20 & 384.60 & -317.20 & 14450.00 \\
6 & -205.50 & 34.90 & 283.00 & -207.40 & 408.20 \\
\hline
\end{tabular}

Table 6. The corrosion parameters of six samples after heat treatment in $3.5 \mathrm{wt} \% \mathrm{NaCl}$, solution.

\begin{tabular}{cccccc}
\hline $\begin{array}{c}\text { Sample } \\
\text { No }\end{array}$ & $\begin{array}{c}\mathbf{E}_{\text {corr }} \\
\mathrm{mV}\end{array}$ & $\begin{array}{c}\mathbf{I}_{\text {corr }} \\
\boldsymbol{\mu} \mathbf{A} / \mathbf{c m}^{2}\end{array}$ & $\begin{array}{c}\text { Tafel Slopes } \\
\boldsymbol{\beta}_{\mathbf{a}} \boldsymbol{\beta}_{\mathbf{c}}\end{array}$ & $\begin{array}{c}\text { Corrosion } \\
\mathbf{m V}\end{array}$ \\
\hline 1 & 371.70 & 6.90 & 81.60 & -316.80 & 80.79 \\
2 & -558.60 & 331.50 & 137.20 & -341.70 & 3877.00 \\
3 & -207.00 & 27.15 & 224.20 & -49.60 & 317.60 \\
4 & -180.80 & 22.34 & 100.00 & -287.40 & 261.30 \\
5 & -353.30 & 39.36 & 493.60 & -917.70 & 460.40 \\
6 & -205.50 & 23.66 & 26.40 & -42.40 & 276.70 \\
\hline
\end{tabular}

Table 7. The corrosion parameters of six stainless steel samples in $3.5 \mathrm{wt} \% \mathrm{NaCl}$ solution

\begin{tabular}{ccccc}
\hline $\begin{array}{c}\text { Sample } \\
\text { No. }\end{array}$ & $\begin{array}{c}\mathbf{E}_{\text {corr }} \\
(\mathbf{m V})\end{array}$ & $\begin{array}{c}\mathbf{E}_{\text {pit }} \\
(\mathbf{m V})\end{array}$ & $\begin{array}{c}\mathbf{I}_{\text {corr }} \\
\boldsymbol{\mu A} / \mathbf{c m}^{2}\end{array}$ & $\begin{array}{c}\text { Corrosion } \\
\text { rate } \boldsymbol{\mu m} / \mathbf{y}\end{array}$ \\
\hline $\mathbf{1}$ & -283.80 & ------- & 2.39 & 27.97 \\
$\mathbf{2}$ & -536.10 & 0.29 & 29.36 & 343.40 \\
$\mathbf{3}$ & -430.40 & 0.37 & 9.13 & 106.80 \\
$\mathbf{4}$ & -390.00 & -------- & 6.17 & 72.23 \\
$\mathbf{5}$ & -439.00 & 0.36 & 12.45 & 145.70 \\
$\mathbf{6}$ & -428.50 & 0.66 & 8.06 & 94.27 \\
\hline
\end{tabular}

Table 8.The corrosion parameters of six stainless steel samples in $5 \mathrm{wt} \% \mathrm{NaCl}$ solution

\begin{tabular}{ccccc}
\hline $\begin{array}{c}\text { Sample } \\
\text { No. }\end{array}$ & $\begin{array}{c}\mathbf{E}_{\text {corr }} \\
(\mathbf{m V})\end{array}$ & $\begin{array}{c}\mathbf{E}_{\text {pit }} \\
(\mathbf{m V})\end{array}$ & $\begin{array}{c}\mathbf{I}_{\text {corr }} \\
\boldsymbol{\mu A} / \mathbf{c m}^{2}\end{array}$ & $\begin{array}{c}\text { Corrosion } \\
\text { rate } \boldsymbol{\mu m} / \mathbf{y}\end{array}$ \\
\hline $\mathbf{1}$ & -370.00 & 0.54 & 33.71 & 394.20 \\
$\mathbf{2}$ & -594.80 & 0.22 & 9964.90 & 116500.00 \\
$\mathbf{3}$ & -440.50 & 0.35 & 1925.10 & 22510.00 \\
$\mathbf{4}$ & -397.20 & 0.50 & 158.79 & 1857.00 \\
$\mathbf{5}$ & -455.10 & 0.32 & 3653.90 & 42730.00 \\
$\mathbf{6}$ & -431.20 & 0.43 & 161.40 & 1887.00 \\
\hline
\end{tabular}

Table 9. The corrosion parameters of six stainless steel samples after heat treatment in $3.5 \mathrm{wt} \% \mathrm{NaCl}$ solution

\begin{tabular}{ccccc}
\hline $\begin{array}{c}\text { Samples } \\
\text { No. }\end{array}$ & $\begin{array}{c}\mathbf{E}_{\text {corr }} \\
\mathbf{m v}\end{array}$ & $\begin{array}{c}\mathbf{E}_{\text {pit }} \\
\mathbf{m v}\end{array}$ & $\begin{array}{c}\mathbf{I}_{\text {corr }} \\
\boldsymbol{\mu A} / \mathbf{c m}^{2}\end{array}$ & $\begin{array}{c}\text { Corrosion rate } \\
\boldsymbol{\mu m} / \mathbf{y}\end{array}$ \\
\hline $\mathbf{1}$ & -70.60 & ---- & 1.80 & 21.11 \\
$\mathbf{2}$ & -540.20 & 0.25 & 56.19 & 762.50 \\
$\mathbf{3}$ & -440.20 & 0.33 & 9.46 & 110.60 \\
$\mathbf{4}$ & -250.80 & ----- & 4.80 & 56.38 \\
$\mathbf{5}$ & -450.10 & 0.32 & 13.36 & 159.70 \\
\hline
\end{tabular}




$\begin{array}{lllll}6 & -435.20 & 0.43 & 8.20 & 96.00\end{array}$

Table 10. EIS parameters of austenitic stainless- steel Alloys in 3.5 wt $\% \mathrm{NaCl}$ Solution

\begin{tabular}{|c|c|c|c|c|}
\hline Conc. of $\mathrm{NaCl}$ & $\begin{array}{c}\text { Sample } \\
\text { No. }\end{array}$ & $\begin{array}{c}\mathbf{R}_{\mathrm{ct}} \\
\text { ohm.cm }\end{array}$ & $\begin{array}{c}\mathbf{C}_{\mathrm{dl}} \\
\mu \mathrm{F} / \mathbf{c m}^{2}\end{array}$ & $\begin{array}{c}\text { Angel } \\
(\theta)\end{array}$ \\
\hline \multirow{6}{*}{ 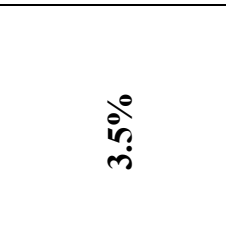 } & 1 & $146.4 \times 10^{6}$ & $1.934 \times 10^{-3}$ & $25.3^{0}-$ \\
\hline & 2 & 1.96 & 202.60 & $29^{0}$ \\
\hline & 3 & 13.00 & 137.00 & -10.5 \\
\hline & 4 & $1.126 \times 10^{6}$ & $5.031 \times 10^{-3}$ & $-18.7^{0}$ \\
\hline & 5 & 9.32 & 140.00 & 23.6 \\
\hline & 6 & 34.21 & 41.67 & -5.24 \\
\hline
\end{tabular}

Table 11. EIS parameters of austenitic stainless- steel Alloys in $5 \mathrm{wt} \% \mathrm{NaCl}$ Solution

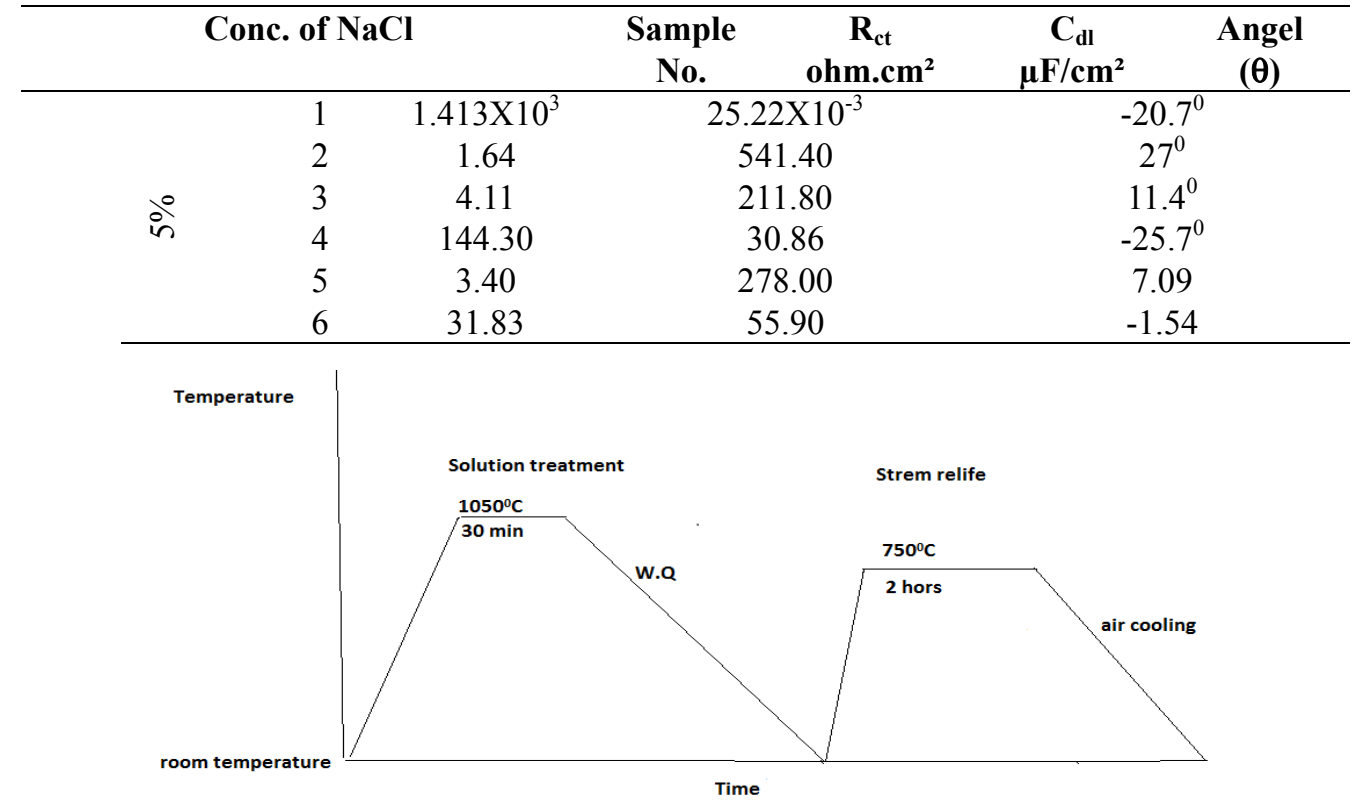

Figure 1. Heat treatment cycle

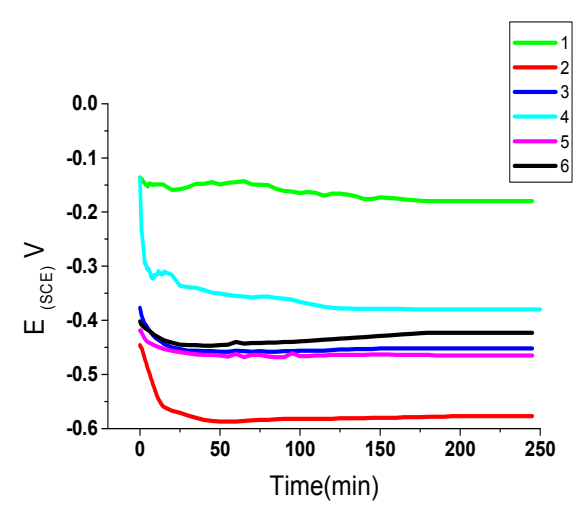

Figure 2. Potential - time curves for samples (1-6) in $3.5 \mathrm{wt} \% \mathrm{NaCl}$ solution.

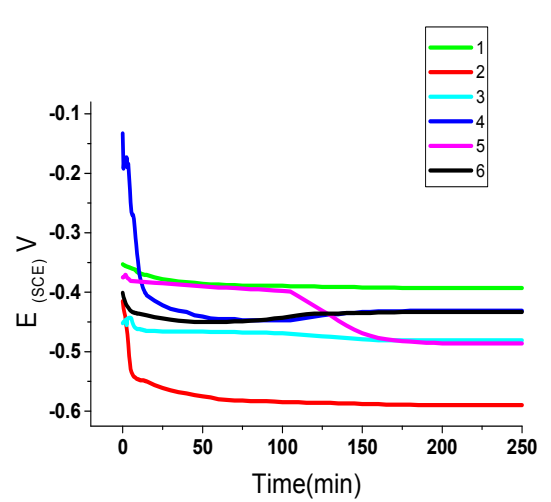

Figure 3. Potential - time curves for samples (1-6) in $5 \mathrm{wt} \% \mathrm{NaCl}$ solution. 


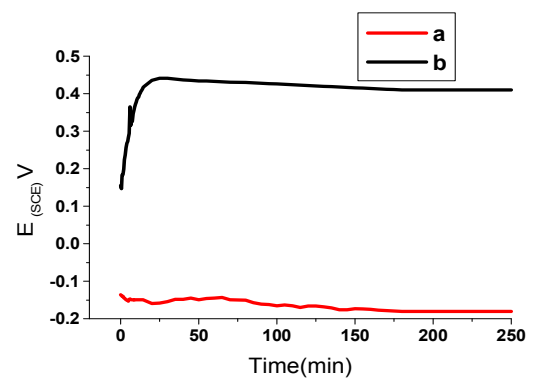

Sample 1

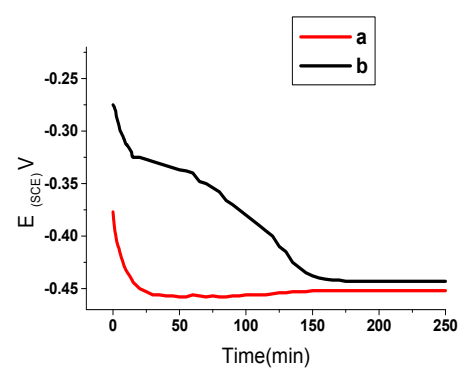

Sample 3

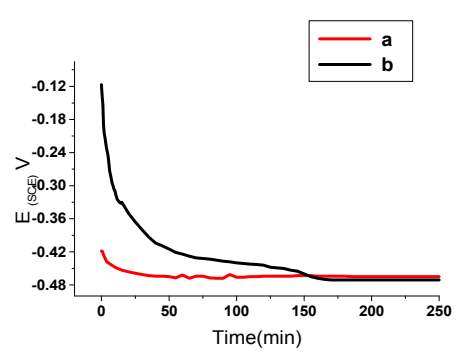

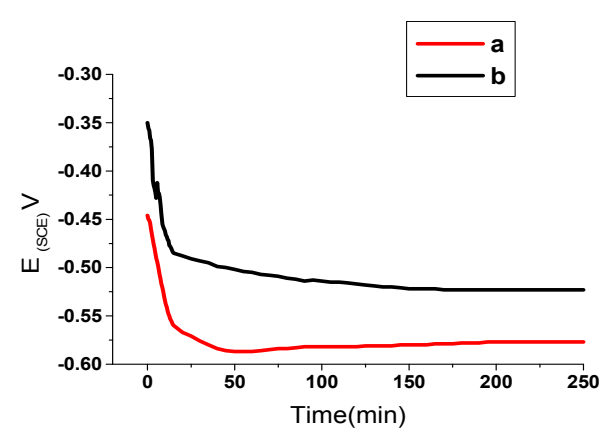

Sample 2

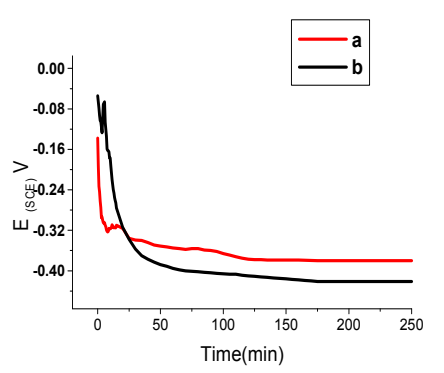

Sample 4

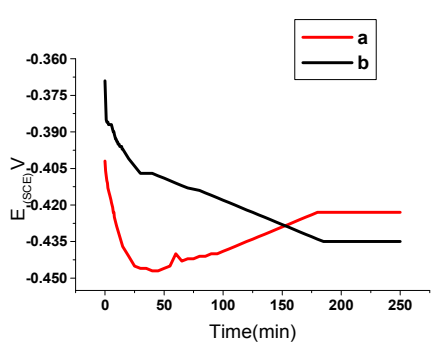

Sample 5

Sample 6

Figure 4. Variation of open - circuit potential for as forged (a) and heat treated (b) Samples (1-6) in 3.5wt $\%$ $\mathrm{NaCl}$ Solution 


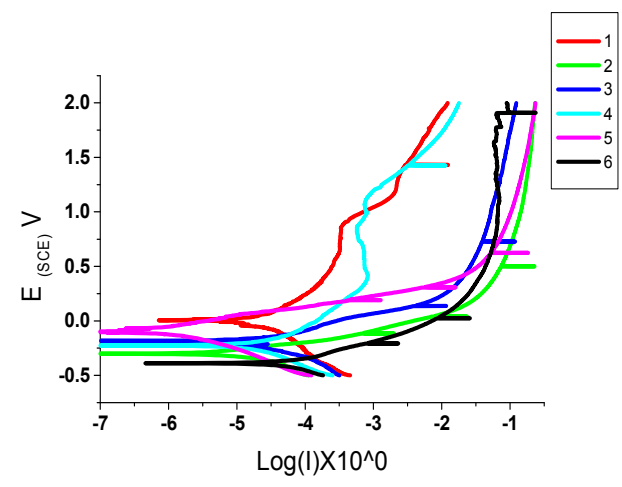

Figure 5. Anodic and cathodic polarization curves for samples (1-6) in $3.5 \mathrm{wt} \% \mathrm{NaCl}$ solution

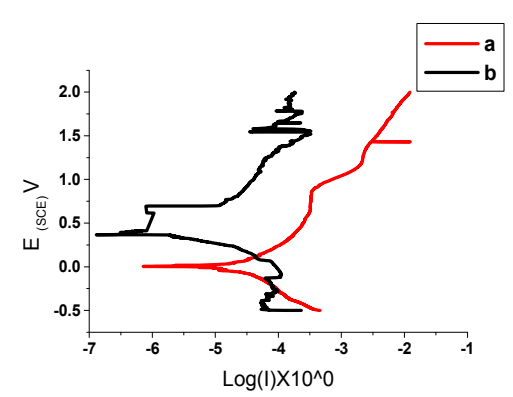

Sample 1

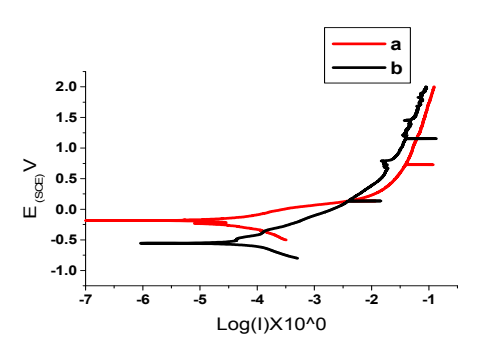

Sample 3

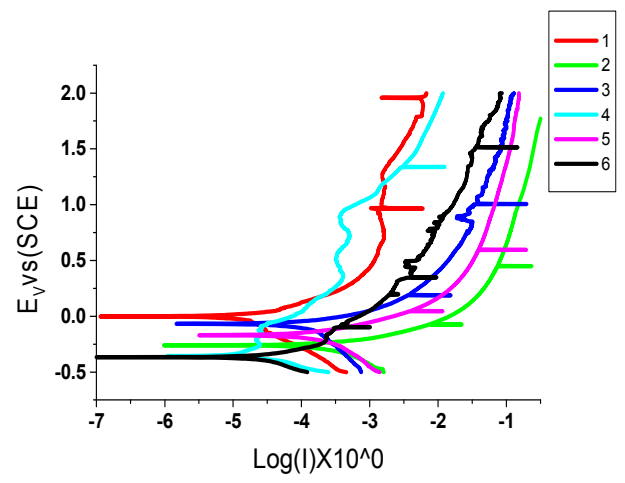

Figure 6. Anodic and cathodic polarization curves for samples (1-6) in $5 \mathrm{wt} \% \mathrm{NaCl}$ solution

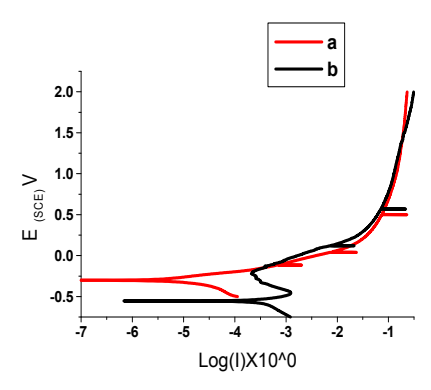

Sample 2

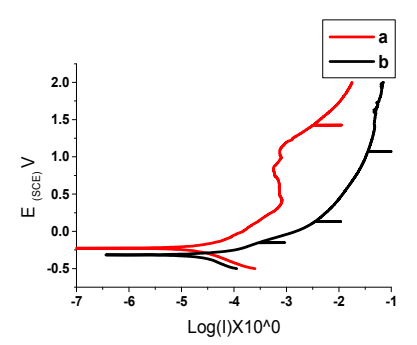

Sample 4 

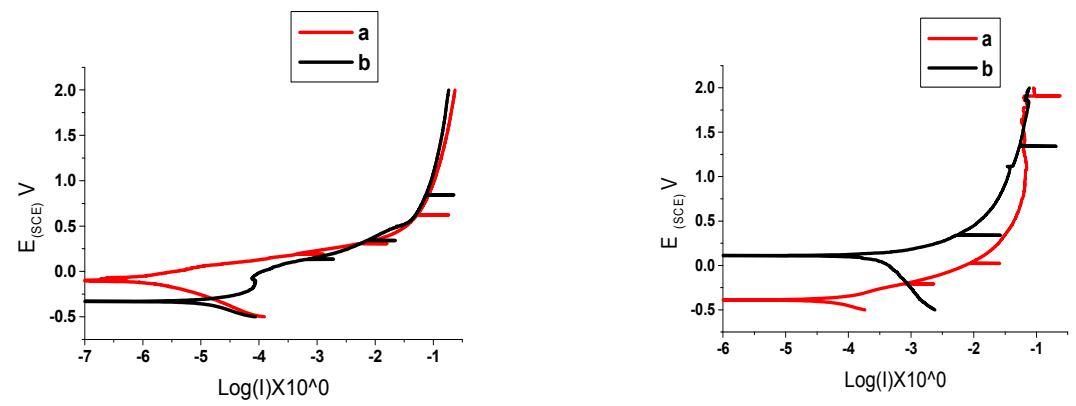

Sample 5

Sample 6

Figure 7. Variation ofPotentiodynamic polarization for as forged (a) and heat treated (b) of Samples (1-6) in $3.5 \mathrm{wt} \% \mathrm{NaClSolution}$

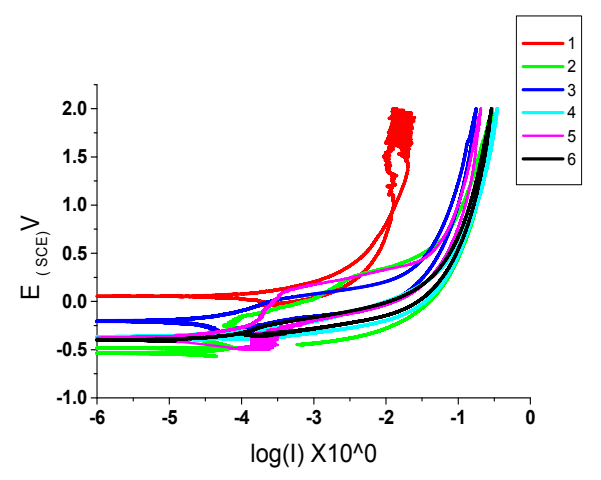

Figure 8. Cyclic anodic polarization curves for samples(1-6) in $3.5 \mathrm{wt} \% \mathrm{NaCl}$ solution

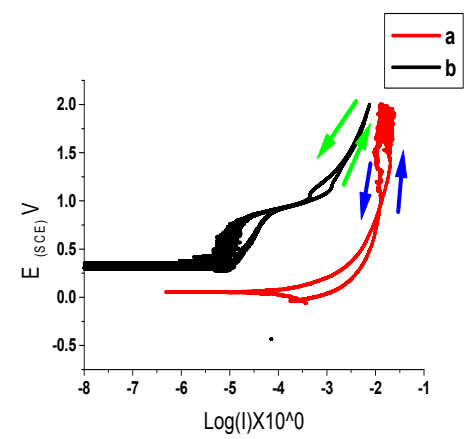

Sample 1

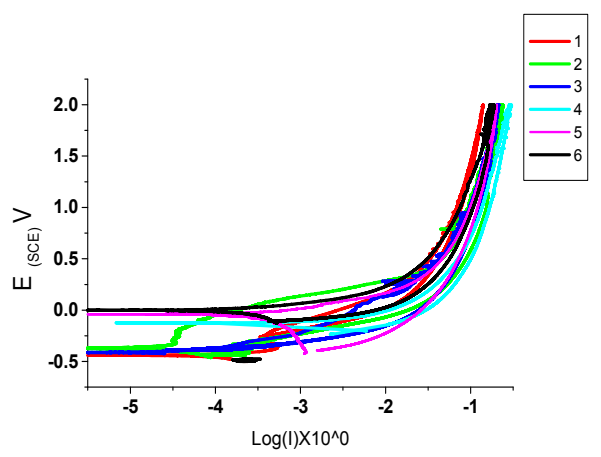

Figure 9. Cyclic anodic polarization curves for samples (1-6) in $5 \mathrm{wt} \% \mathrm{NaClSolution}$

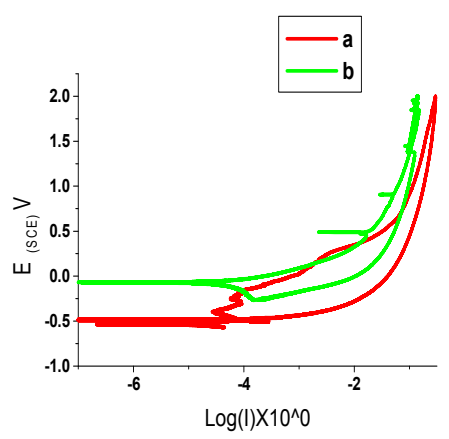

Sample 2 

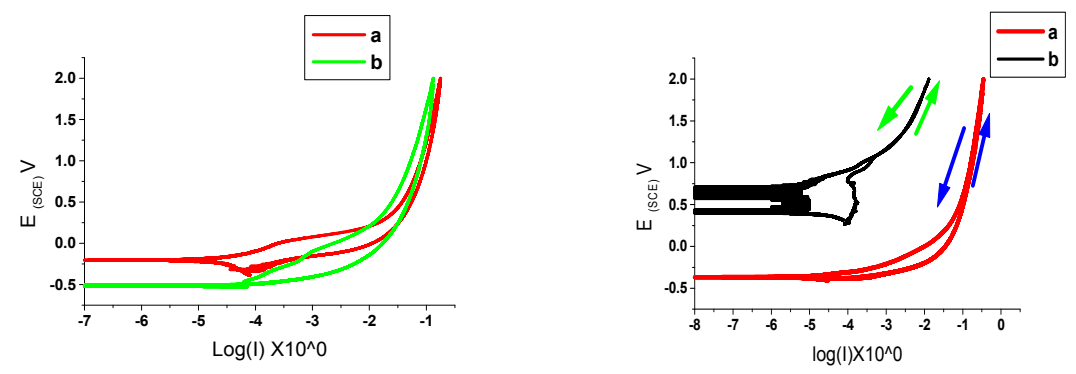

Sample 3
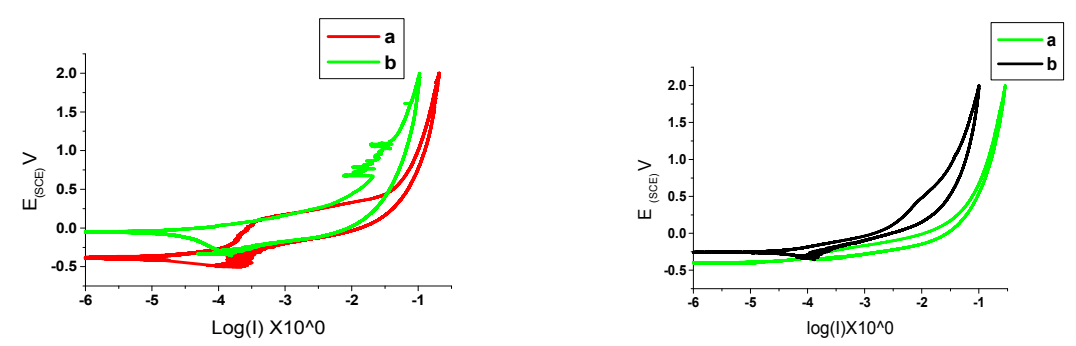

Sample 5

Sample 6

Figure 10. Variation of cyclic anodic polarization for as forged (a) and heat treated (b) of samples (1-6) in $3.5 \mathrm{wt} \% \mathrm{NaCl}$ solution

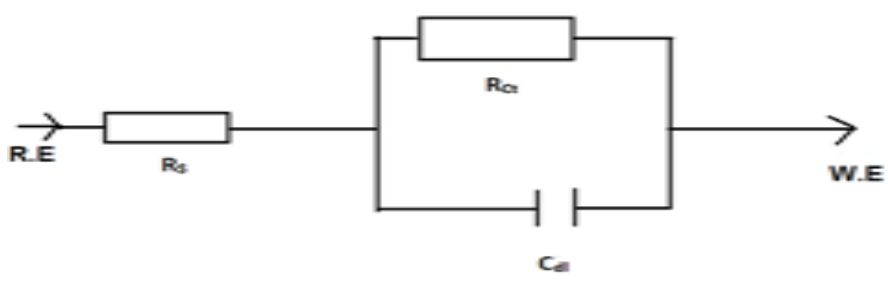

Figure 11. Electric equivalent circuit model used to fit the results of impedance

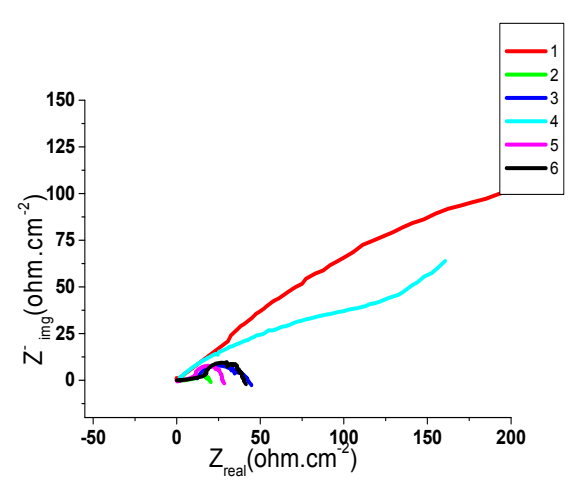

Figure 12. Nyquist plots for samples in $3.5 \mathrm{wt} \% \mathrm{NaCl}$ solution

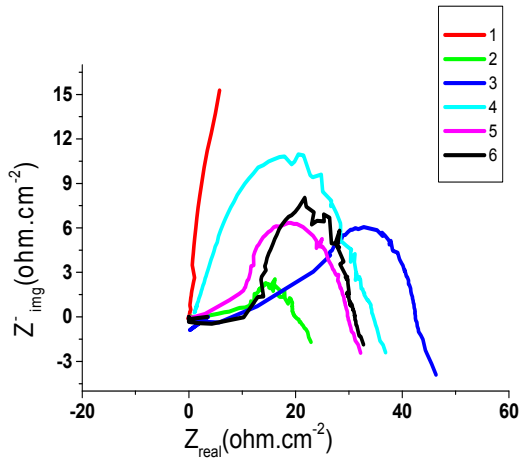

Figure 13. Nyquist plots for samples in $5 \mathrm{wt} \% \mathrm{NaCl}$ solution 

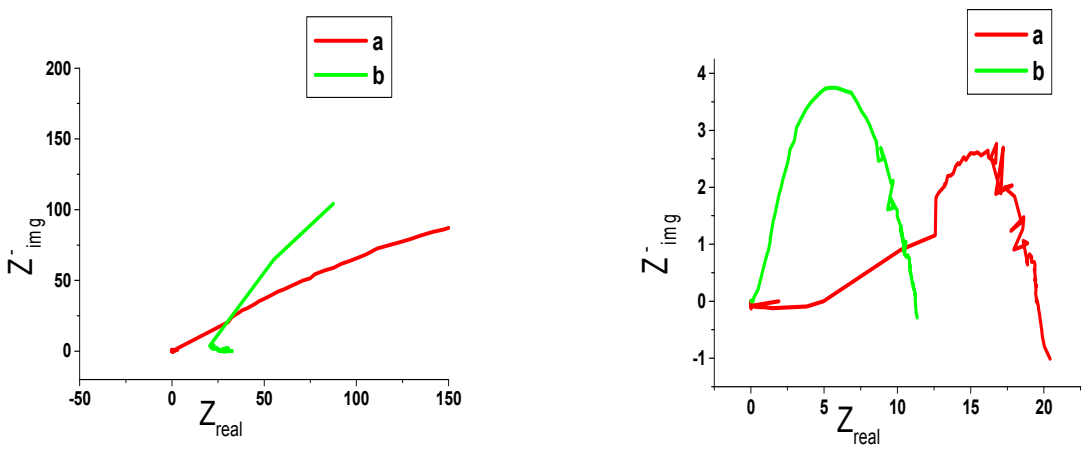

Sample 1

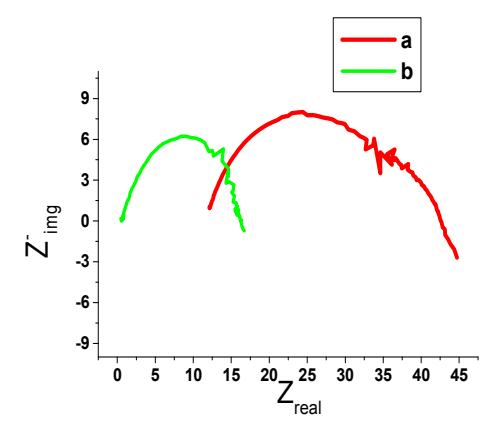

Sample 3

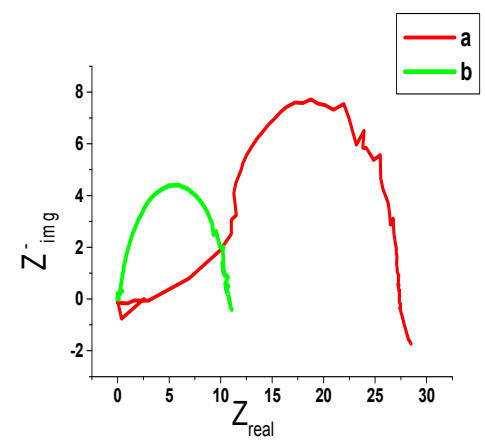

Sample 5

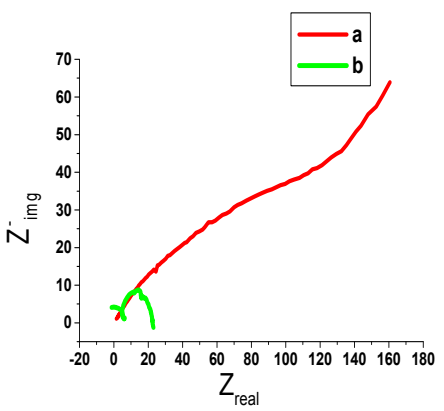

Sample 4

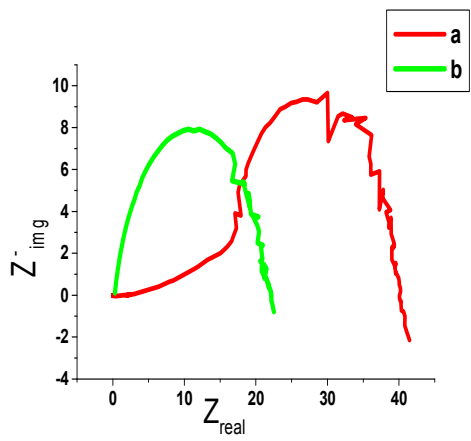

Figure 14. Variation of Electrochemical impedance for as forged (a) and heat treated (b) of Samples (1-6) in $3.5 \mathrm{wt} \% \mathrm{NaCl}$ solution 


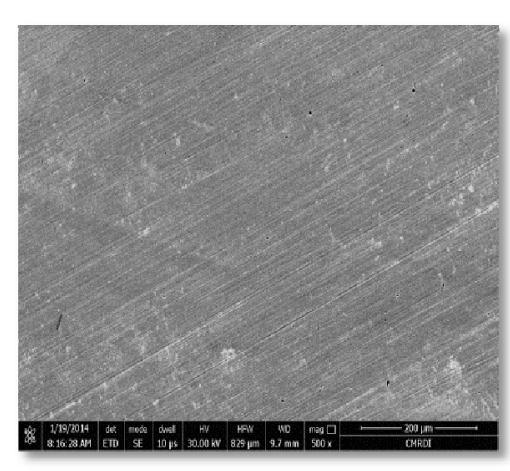

(a). Sample1

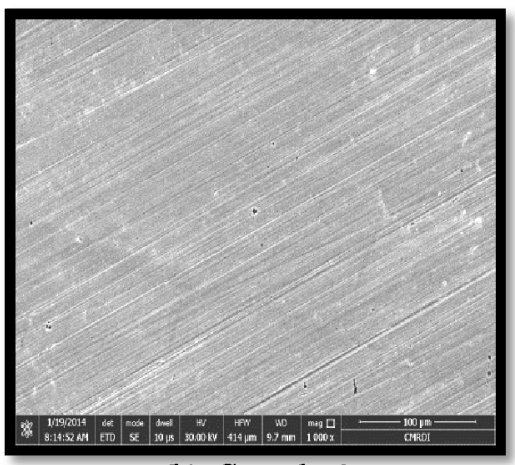

(b). Sample 4

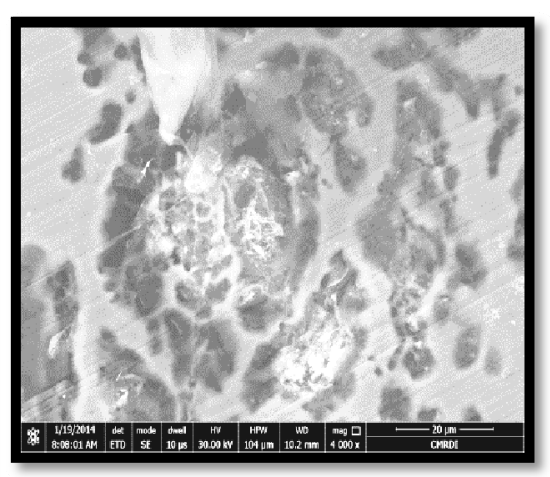

(c). Sample 2

Figure 15. Surface morphology of samples in $3.5 \mathrm{wt} \% \mathrm{NaCl}$ solution

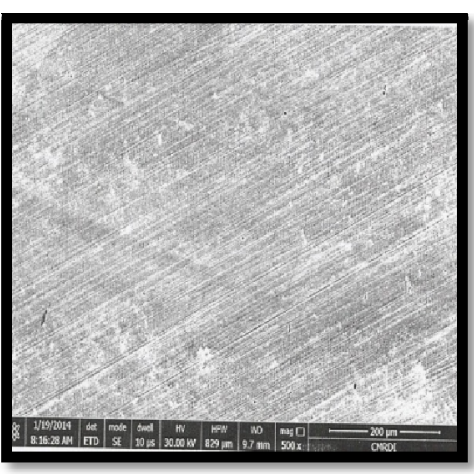

(a). Sample 1

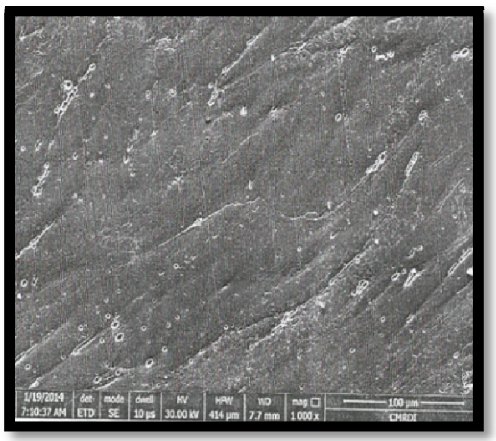

(b). Sample 4

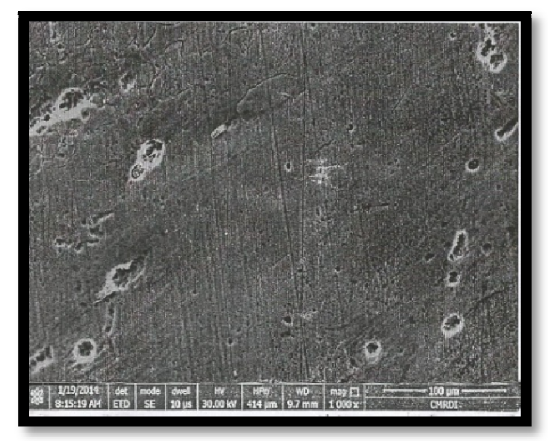

(c). Sample 2

Figure 16. Surface morphology of samples in $3.5 \mathrm{wt} \% \mathrm{NaCl}$ solution after heat treatment

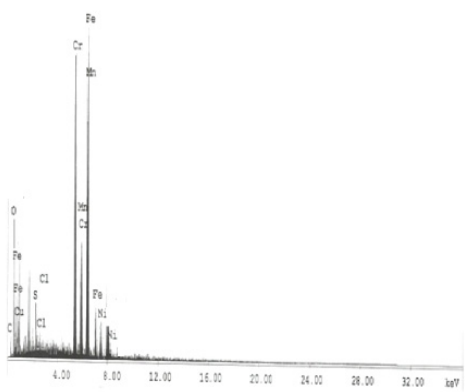

(a). Sample1

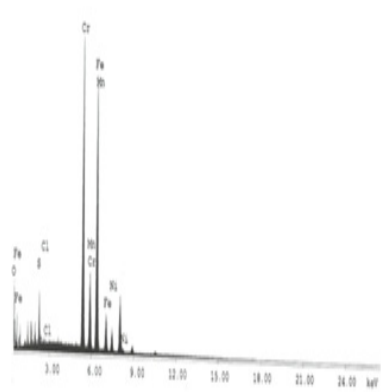

(b). Sample 4

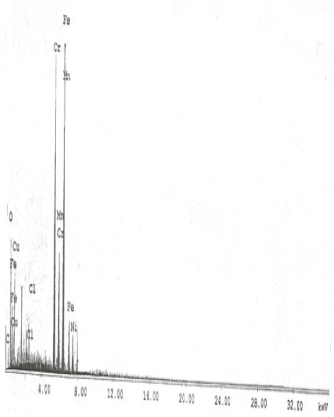

(c). Sample 2

Figure 17. EDAX spectra Surface morphology of samples in $3.5 \mathrm{wt} \% \mathrm{NaCl}$ solution

\section{Copyrights}

Copyright for this article is retained by the author(s), with first publication rights granted to the journal.

This is an open-access article distributed under the terms and conditions of the Creative Commons Attribution license (http://creativecommons.org/licenses/by/3.0/). 